\title{
The Relationship Between Education and Agricultural Productivity: The Moderating Effect of NGO
}

\author{
Salisu Ahmed Kabiru \\ Department of Public Administration, Faculty of Social and Management Sciences, Umaru Musa Yar'adua University, Katsina, Nigeria
}

Received December 1, 2019; Revised January 14, 2020; Accepted February 7, 2020

Copyright $(2020$ by authors, all rights reserved. Authors agree that this article remains permanently open access under the terms of the Creative Commons Attribution License 4.0 International License

\begin{abstract}
The importance of education on all aspect of human endeavor is incontestable as education plays a significant role in human and economic development of a nation. Many studies around the globe have proved that education is the most potent tool in poverty reduction effort. This is because as the level of education increases the probability of becoming poor also reduces. The purpose of this study is to examine the moderating effect of NGO on the relationship between education and agricultural productivity in Katsina State Nigeria. The study adopted a quantitative method by using questionnaire as the instrument for data collection. A total of 430 questionnaires was distributed to the respondents from the six-local government of the state and 410 were returned accounting for 95 percent rate of return and 400 screened questionnaires was used for further analysis. Partial Least Square-Structural Equation Modelling PLS-SEM was used as data analysis tools. The major finding of the study indicated that, there exists positive relationship between education and agricultural productivity and NGO also moderate the relationship between education and agricultural productivity. Conclusively this study revealed that education is a viable mechanism for improving agricultural productivity. This study suggested that, government at various level should partner with NGO in bringing about development, especially of the rural areas. This study has contributed to the literature in development studies as this study is the first to introduce NGO as a moderating variable in development study.
\end{abstract}

Keywords Education, NGO, Agricultural Productivity

\section{Introduction}

From a global perspective, the progress of a nation is dependent upon the level of education of its citizen education. Education has been identified by many studies as the basic building block of every society. Education is the sole best investment a country can make toward establishing a prosperous, equitable and healthy society (1\&2). The importance of education on all aspect of human endeavor is incontestable as education plays a significant role in human and economic development of a nation. It is also acknowledged that education is the most potent tool in poverty reduction effort as many studies have shown that there is a positive and significant relationship between education and poverty reduction $(3 \& 4)$.

Furthermore, recent studies such as $(5 ; 6 ; 7)$ have found a significant and positive relationship between education and agricultural productivity. Education affects agricultural productivity in a number of ways, first by increasing farmers' adoption of new technologies and subsequently by increasing the ability of the farmers to produce more output from given resources through efficient use of the introduced technologies. Similarly, education is expected to accelerate agricultural productivity by enhancing the productive capabilities of all producers by exposing them to a more systematic and dynamic production system and by enhancing their ability to choose the optimal levels of inputs and outputs (8).

Previous studies such as $(9 ; 10 ; 11 ; 12 ; 13)$, have focused on the development of agriculture sector by government as the means of developing the rural areas, thereby neglecting the role of NGO as a partner in development effort. Based on the above background, this study examines the moderating effect of NGO on the relationship between education and agricultural productivity in Katsina state Nigeria. Significantly, this study has for the first time introduce NGOs as a moderator in development studies literature to support the independent variable in the study which has never been done before to the knowledge of the researcher. Additionally, this study has made a breakthrough for up-coming researchers to explore the potentialities of NGOs in supporting development effort in 
other regions which will invariable add knowledge to development studies literature globally. Moreover, for the first time, these two variables were combined in a single model and found their relationship which was hitherto not been done. In addition, the construct of this study and their relationship were majorly investigated in Western and Asian context. Investigating the construct in a different context which is Katsina state Nigeria is another uniqueness of this study.

\section{Literature Review}

Academic study on modern NGOs was a recent development, as the first set of academic literature on NGOs emerged in 1990s, such as the work of (14), (15), and (16). While these works were mainly case studies in approach, substantial number of these studies that were available on the net were conducted in the Western context which has a different perception of rural development, thus creating a vacuum to be fill from other contextual perspective such as Africa and Asia.

The following decades witnessed a tremendous increase of literature on NGO from both Europe and Asia such as the works of (18), and (19). The second-generation of scholars were also skewed to the West, while in Africa, study on NGOs was scanty up to this time as to the knowledge of the scholar, only few studies were conducted on NGOs in Africa such as the work of (1), and recently by (2) in Ghana. Based on this background, this present study was conducted in West Africa Nigeria, in order to expand the frontier of knowledge from a different and a newer context.

The role of NGOs in both urban and rural development has been recognized by the United Nation and the World Bank by officially listing some NGOs as development partners. NGOs have played a significant and key role in advocating for sustainable development at the international level which led to the initiation and implementation of Millennium Development Goal (MDG) in the beginning of the 1990s. NGOs have been in the fore front in the campaign for the eradication of poverty, especially in low income countries as well as agitation for the eradication of hunger, diseases, environmental degradation, and employment generation (1).

In a study conducted by (20) NGOs have been found to be a key factor for the successful development of farmer cooperatives in Northwest of China. In a related study conducted in Zimbabwe by (21), it was found that NGOs contributed significantly towards the improvement of the livelihoods of farmers in ward 5 of Mutasa District in Manicaland Province of Zimbabwe. A recent study by (22) found that, NGOs contribution to agricultural development centers not only on farm implement, but they venture into areas of research, extension services, technology transfer, institutional capacity development, innovation and effective policy implementation mechanism.

In a study by (23), it was found that NGOs has contributed to the development of agriculture in rural Rwanda ranging from extension work to the distribution of agricultural inputs, increasing agricultural production, revenues, and food security. It was also found that, within the agricultural sector, NGOs were involved in poverty reduction programs as well as improving the quality of life of the most vulnerable poor. NGOs also engage in eradication of injustice, and promoting greater equity, peace, and reconciliation.

(24) investigated the role of NGOs in agricultural development in coastal region of Kenya, and 11 out of 25 NGOs that were in the region were found to be active in agricultural development. The study also found that, NGOs were able to trained 39 extension officers among the rural people, and they were also able to establish contact with 196 farmer groups that comprises 5,320 farmers. It was also found that, the NGOs participate in other field such as health, water, and micro-enterprise development.

Based on the above literature, the following hypotheses were postulated as follows:

1.There is significant relationship between education and agricultural productivity

2.NGO moderate the relationship between education and agricultural productivity

\section{Methodology}

Specifically, the population of this study consist of all the 34 local governments of Katsina which stand at five million eight hundred thousand five hundred and eight four people as at the last population census of 2006. Katsina state is located in the North-Western part of Nigeria, bordering with Kaduna by the West, Kano by the East, Sokoto and Zamfara by the South and Niger republic by the North. In order to select the sample from the population, the population of this study was divided into three Senatorial Zones, zone A, consist of 11 local governments areas, Zone B consist of 11 local government while Zone $\mathrm{C}$ consist of 12 local government, and in each of the zones two local government areas were selected from where the sample was drawn. Multistage and purposive sampling techniques were used in drawing the sample. The multistage sampling cluster design is useful when a researcher is faced with a large population $(25 ; 26 ; 27 ; 28)$.

By using (29) sampling technique 384 was arrived as the sample size of the study, however, in order to make the sample more representative and avoid the issues of bias, sampling error, and non-responses as suggested by (30),(31), and (32), the sample was increased to 430 and after data screening a useable 400 responses was used for analysis. The distribution of sampling is indicated in table 1 below. 
Table 1. Distribution of Sample Size

\begin{tabular}{|c|c|c|}
\hline Local Areas & Population & Sample Size \\
\hline Jibia & 167,435 & 63 \\
\hline Batagarawa & 189,059 & 71 \\
\hline Daura & 224,884 & 85 \\
\hline Mashi & 171,070 & 64 \\
\hline Danja & 125,481 & 47 \\
\hline Sabuwa & 140,679 & 54 \\
\hline Total & $1,018,608$ & 384 \\
\hline
\end{tabular}

\section{Data Analysis}

The statistical tool adopted for this study is PLS-SEM as it's the most widely used tool of analysis in social and behavioral sciences disciplines in analyzing relationship between and among complicated variables. Additionally, PLS exhibit strong statistical accuracy and reliability than other statistical tool having the power to run multiple regression analysis simultaneously (33Tabri,).

\section{Result and Discussion}

The result and discussion of the analysis of the relationship between the construct of this study will be in two segments, the first part will discuss the result of the measurement model analysis, while the second part will discuss the result of the analysis of the structural model.

\section{Measurement Outer Model}

The assessment of the measurement model was done in steps, in the first step the internal consistency of the items was determined where each item indicate a significance contribution in measuring the variable or construct, and in the second step, the measurement model was verified through construct reliability test (composite reliability, convergent validity, and Cronbach Alpha). It is essential in quantitative research to meet the requirement for reliability and validity before further analysis is carry (34 Hair,).

Table 2. Construct reliability and validity

\begin{tabular}{|c|c|c|c|c|c|c|}
\hline Construct & Items & Loadings & CA & rhe & CR & AVE \\
\hline Agriculture & A1 & 0.721 & 0.762 & 0.775 & 0.847 & 0.581 \\
& A10 & 0.737 & & & & \\
& A11 & 0.787 & & & & \\
& A6 & 0.802 & & & & \\
\hline Education & E1 & 0.814 & 0.922 & 0.932 & 0.939 & 0.721 \\
& E2 & 0.838 & & & & \\
& E3 & 0.798 & & & & \\
& E4 & 0.894 & & & & \\
& E5 & 0.926 & & & & \\
\hline NGO & N1 & 0.795 & 0.882 & 0.898 & 0.913 & 0.678 \\
& N2 & 0.838 & & & & \\
& N3 & 0.811 & & & & \\
& N4 & 0.892 & & & & \\
& N5 & 0.777 & & & & \\
\hline
\end{tabular}

For this study to meet the measurement validity requirement, convergent validity was carry out by assessing the loadings, average variance extracted (AVE) and composite reliability (CR) as well. As indicated in table 2, the loadings were all above the standard value of 0.4 $(35$,).The CR,CA, and rho- were all greater than 0.6 ,similarly, AVE value was greater than the threshold of 0.5 (35 Hair,).

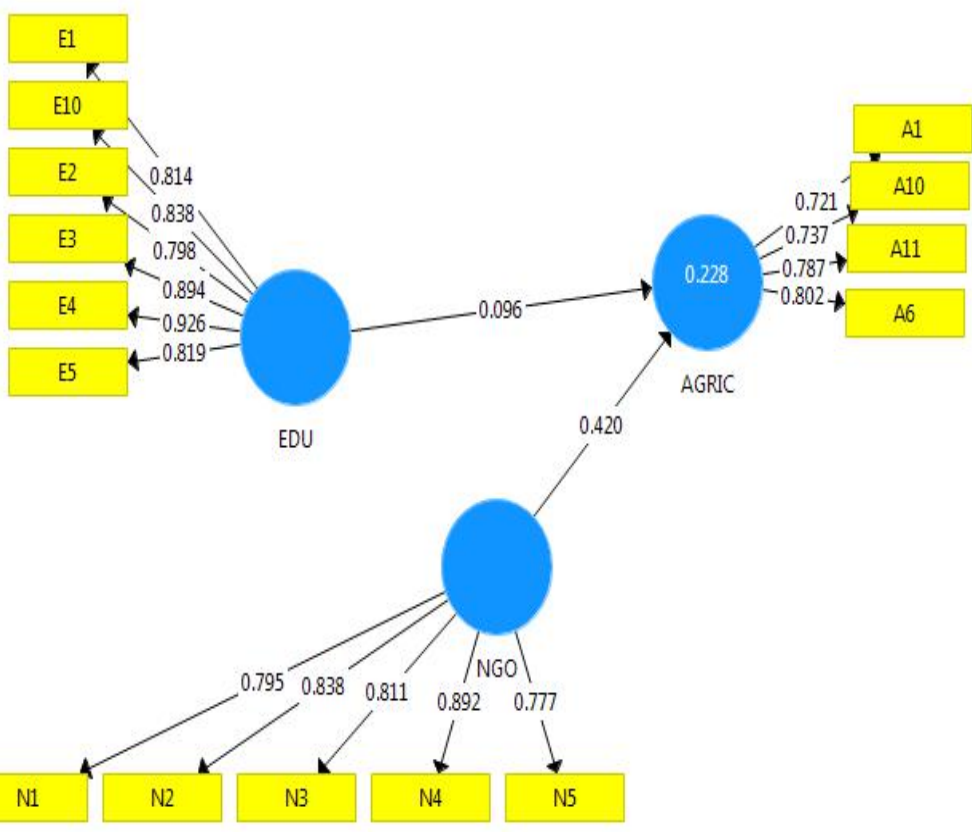

Figure 1. Measurement model 
This study determined the direct relationship between education and agricultural productivity using bootstrapping and the result of the analysis indicates that there exist positive relationship, $\mathrm{STD}=0.057, \mathrm{TV}=4.390, \mathrm{P}=0.000$, therefore the first hypothesis which says there is significant relationship between education and agricultural productivity was supported. The moderating effect was also analyzed and result shows that, $\mathrm{STD}=0.025, \mathrm{TV}=5.054, \mathrm{P}=0.000$, and therefore, the hypothesis which says NGOs moderates the relationship between education and agricultural productivity is supported. The result of this analysis is indicated in table 3 and figure 2 respectively.

Table 3. Result of the structural model assessment (hypothesis testing

\begin{tabular}{|c|c|c|c|c|}
\hline Relationship & Std & $\mathrm{T}$ & $\mathrm{P}<$ & Decision \\
\hline Education & 0.057 & 4.390 & 0.000 & Significance \\
Effect & 0.025 & 5.054 & 0.000 & Significance \\
\hline NGOs & 0.038 & 11.145 & 0.000 & Significance \\
\hline
\end{tabular}

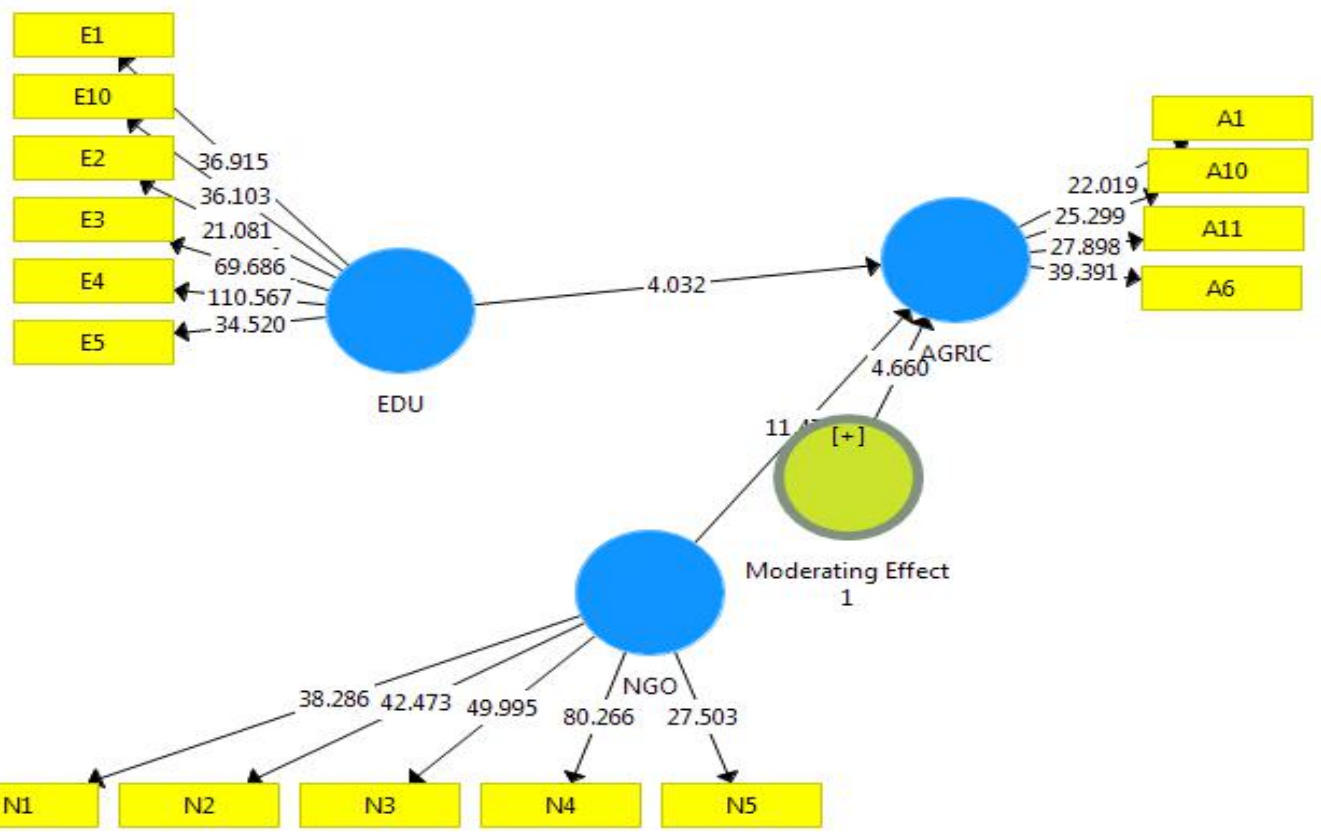

Figure 2. Structural Model

\section{Discussion, Implication, Limitation, Future Research}

Using the PLS statistical tool, this study has investigated the direct relationship between education and agricultural productivity and the moderating effect of NGOs between education and agricultural productivity. The PLS-SEM is a statistical soft-ware application which most widely used in the social sciences field. One of the advantages of PLS-SEM is its ability to perform multiple regression analysis simultaneously on two or more variables accurately. Using the PLS-SEM application this study, has established, the relationship between education and agricultural productivity which was analyzed through bootstrapping and the result indicated a significant relationship as shown in table 3 and figure 2 respectively. The moderating effect was analyzed, and the result reveal that, NGOs moderate the relationship between education and agricultural productivity significantly.

The result which indicated that, STD 0.057, TV 4.390, P 0.000 has proved that there is significant relationship between education and agricultural productivity, and it has yet provided another evidence that, education is a leeway for agricultural productivity and this finding is in line with the theoretical and empirical findings from other studies..

\section{Implication of the Result}

One of the major explicit implication for policy makers on agricultural productivity and by extension rural development as drawn from this study is that, education has a significant influence on agricultural productivity which implies that, the more people are educated the more productive they could become. Hence, government should 
provide more school in the rural areas to reduce the rate of illiteracy among the rural dwellers. Another implication as drawn from the finding of this study, was that NGOs, play a significant role in helping rural people to enhance their agricultural productivity, as such government should explore avenue of attracting more NGOs to work together as partners in development thrive.

\section{Limitation, and Future Research}

One of the limitations of this study was that, its correlational in nature which is confined to establishing relationship among and within variables without causal relationship. Future study should consider investigating the causal relationship to overcome this limitation. This study is a cross-sectional study which was carry out within a specified period mostly 3 to 4 years. Future should overcome this limitation by conducting a longitudinal study to compliment the short coming of this study. For the first time NGOs was used as a moderator in the Nigerian context, future study should be carry out in another context to broaden the understanding of the variables to supplement the findings of this study.

\section{Conclusions}

Conclusively, this study has examined the moderating effect of NGOs on the relationship between education and agricultural productivity. The result from the analysis shows that NGOs moderates the relationship between education and agricultural productivity which implies that the more NGOs participate in the provision of education the more farmers will enhance their agricultural productivity. From the findings of this study, it has been proved that to facilitate and realized rural development objective, government and other sectors must come together and work simultaneously then agricultural productivity will be enhance and by extension rural development.

\section{REFERENCES}

[1] Vivian, J. NGOs and sustainable development in Zimbabwe: No magic bullets. Development and Change, 25, 181-209, 1994

[2] Bright, E .B. The role of NGOs in rural development: A case study of World Vision Ghana in Mfantesman District. (A project submitted to Department Of Geography And Rural Development Faculty Of Social Sciences, College Of Arts And Social Sciences, Kwame Nkrumah University Of Science And Technology, Kumasi) 2013

[3] Ullah, A. K. M., \& Routray, J. K. Rural poverty alleviation through NGO interventions in Bangladesh: how far is the achievement? International Journal of Social
Economics, 34(4), 237-248. 2007

[4] Oladapo, F. M., Adeniyi, I. M., Adebagbo, C. A., \& Ayetan, G.. Utilization of some selected wood species in relation to their anatomical features. Global Journal of Science Frontier Research Agriculture and Veterinary, 13(9), 2249-4626, 2013

[5] Knickel, K., Brunori, G., Rand, S., \& Proost, J. Towards a better conceptual framework for innovation processes in agriculture and rural development: from linear models to systemic approaches. Journal of Agricultural Education and Extension, 15(2), 131-146, 2009

[6] Sicilian,G. Urbanization strategies, rural development and land changes in China: a multi-level integrated assessment. Land Use Policy, 29 (4), 165-178, 2012

[7] Hamzel, B. Education for rural development a new paradigm shift. Journal of Administrative Studies.5,(9),1133-1140, 2014

[8] Kabiru, S. A., \& Arshad, R.. The Effect of Education on Agricultura Productivity: Implication for Rural Development. Studies, 1(6), 28-35. 2019

[9] Dethier, J. J., \& Effenberger, A.. Agriculture and development: A brief review of the literature. Economic Systems, 36(2), 175-205. 2012

[10] Chimhowu, A. Aid for agriculture and rural development in the global south: A changing landscape with new players and challenges (WIDER Working Paper.No. 2013/014). Retrieved from https://scholar.google.com/scholar?hl=en\&as_sdt=0\%2C5\& $\mathrm{q}=$ Chimhowu $\% 2 \mathrm{C}+\mathrm{A} .+\% 282013 \% 29 .+\mathrm{Aid}+\overline{\text { for }}+$ agriculture +and+rural+development+in+the + global+south\%3, 2013

[11] Chambers, R. Rural development: Putting the last first. London: Routledge. 2014

[12] Petrascu, S. The impact of investment management on the evolution of the agri-food export in the Republic of Moldova. Series" Management, Economic Engineering in Agriculture and rural development, 15(2), 255-258. 2015

[13] Parihar, S. S., Mishra, B., \& Rai, D. P.. Sustainable models of information technology for agriculture and rural development. Indian Research Journal of Extension Education, 10(1), 20-23. 2016

[14] Clark, J. (1991). Democratising development: The role of voluntary organizations. London: Earthscan. 1991

[15] Korten, F. F. \& Bagadion, B. U (1991). Developing irrigators' organizations: A learning process approach. Putting people first: Sociological variables in rural development, 2, 73-112. 1991

[16] Fowler, B. Pierre Bourdieu and cultural theory: Critical investigations (Vol. 48). Sage. 1997

[17] Hilhorst, D. (2003). The real world of NGOs: Discourses, diversity and development. London: Zed Books. 2003

[18] Igoe, J., \& Kelsall, T. (Eds.).. Between a rock and a hard place: African NGOs, donors and the state. Carolina Academic Press. 2005

[19] Garnevska, E., Liu, G., \& Shadbolt, N. M. (2011). Factors for successful development of farmer cooperatives in Northwest 
China. International Food and Agribusiness Management Review, 14(1030-2016-82904), 69-84. 2011

[20] Mandirahwe, Impact of NGOs intervention on capacity development of small scale farmers: a case of ward 5 of Mutasa district. 2016

[21] Ahmad, M. M. NGO field workers in Bangladesh. UK: Routledge. 2017

[22] Bingen, R. J., \& Mpyisi, E.. Non-Governmental Organizations in Agricultural Development: Kigali: FSRP. 2015

[23] Ndungu, J., De Groote, H., \& Danda, K.. Non-governmental organizations and agricultural development in the coastal region of Kenya. Retrieved from https://scholar.google.com/scholar?hl=en\&as_sdt=0\%2C5\& $\mathrm{q}=\mathrm{Ndungu} \% 2 \mathrm{C}+\mathrm{J} . \% 2 \mathrm{C}+\mathrm{De}+$ Groote $\% 2 \mathrm{C}+\mathrm{H} . \% 2 \mathrm{C}+\% 26+\mathrm{Da}$ nda $\% 2 \mathrm{C}+\mathrm{K} .+\% 282015 \% 29 .+$ Non-governmental+organizati ons + and + agricultural + development + in + the + coastal + region + of + Kenya.\&btnG $=, 2015$

[24] Babbie, E. The practice of social research. UK: Wadsworth. 2013

[25] Bougie, R. \& Sekaran, U.. Research methods for business: A skill building approach. UK: John Wiley \& Sons. 2016

[26] Etikan, Il., Bala, K. Combination of Probability Random Sampling Method with Non Probability Random Sampling Method (Sampling Versus Sampling Methods). Biometrics \& Biostatistics International Journal,5(6). 2017

[27] Creswell, J. W., \& Creswell, J. D. Research design: Qualitative, quantitative, and mixed methods approaches. USA: Sage Publications. 2017

[28] Saunders, M. N.. Research methods for business students. India: Pearson Education. (007

[29] Salkind, N. J. . Exploring research. UK: Sage. 2014

[30] Dolnicar, S. B. Grün, F. Leisch, K. Schmidt. Required sample sizes for data-driven market segmentation analyses in tourism. Journal of Travel Research, 53 (3) , 296-306, 2014

[31] Lewis, S. Qualitative inquiry and research design: Choosing among five approaches. Health Promotion Practice, 16(4), 473-475. 2015

[32] Tabri, N., \& Elliott, C. M. (2012). Principles and practice of structural equation modeling. Canadian Graduate Journal of Sociology and Criminology, 1(1), 59-60. 2012

[33] Hair, F, J., Sarstedt, M., Hopkins, L., \& G. Kuppelwieser, V. (2014). Partial least squares structural equation modeling (PLS-SEM) An emerging tool in business research. European Business Review, 26(2), 106-121.

[34] Hair, F, J., Sarstedt, M., Hopkins, L., \& G. Kuppelwieser, V.. Partial least squares structural equation modeling (PLS-SEM) An emerging tool in business research. European Business Review, 26(2), 106-121, 2014

[35] Hair, F, J., Sarstedt, M., Hopkins, L., \& G. Kuppelwieser, V. (2014). Partial least squares structural equation modeling (PLS-SEM) An emerging tool in business research. European, 2014 